\title{
EMERGING TRENDS IN INDIAN BANKING SERVICES - CHALLENGES AND OPPORTUNITIES
}

\author{
Dr.Raju Paila ${ }^{1}$, Dr.Surya Prakasa Rao Gedela ${ }^{2}$, Dr.Srinivasa Rao Pasala ${ }^{3}$ \\ ${ }^{I}$ Faculty, Dwaraka Nagar campus, Gayatri Vidya Parishad College for Degree and P.G.Courses (A), \\ Visakhapatna
}

${ }^{2}$ Faculty, School of Management Studies, Rushikonda campus, Gayatri Vidya Parishad College for Degree and P.G.Courses (A), Visakhapatnam.
${ }^{3}$ Faculty, M.V.P campus, Gayatri Vidya Parishad College for Degree and P.G.Courses (A), Visakhapatna

Article DOI: https://doi.org/10.36713/epra7975

DOI No: $10.36713 /$ epra7975

\begin{abstract}
The economic and financial environment in which the Indian banking system is operating is evolving continuously. Developments in global banking are likely to be conditioned by proposed regulatory changes aimed at ring-fencing commercial banking activities. Today banking is known as innovative banking. Information technology has given rise to new innovations in the product designing and their delivery in the banking and finance industries, customer services and customer satisfaction are their prime work. One of the most significant areas where IT has had a positive impact so on substitutes for traditional funds movement services. With the advent of electronic banking electronic funds transfer and other Similar products funds transfer within time frames which would have appeared impossible a few years age. With networking and inter connection new challenges are arising related to security privacy and confidentiality to transactions. Finally the banking sector will need to master a new business model by building management and customer services with a variety of products and controlled cost to stay in the long run.
\end{abstract}

KEYWORDS: Environment, Information technology, satisfaction, banking, customer

\section{INTRODUCTION}

Banks constitute an important segment in financial arena of all countries whether developed or developing or underdeveloped. Economic development of every country depends upon financial sector particularly commercial banks. In fact economic development and financial infrastructure go hand in hand. From time immemorial, the conventional banker, an indispensable pillar of Indian society, giving and taking of credit in one form or another, must have existed as earlier as the Vedic period. Money lending was one of the recognised occupations under Manu's laws'. The history of modem Indian banking goes back to 1683 when the first Indian Bank was established on western lines in Madras. The establishment of the Bank of Calcutta in
1806 marked the beginning of the modern banking era in India. But the present Indian banking system had developed considerably since 1935 . RBI has started its operation in 1935 through an Act. A critical review of the growth of banking in India in the pre independence period reveals that the banking system had neither a definite shape nor policy except the creation of RBI in 1935. With the enactment of the Banking Companies Act in 1949, the Indian banking system had undergone substantial changes structurally, geographically and functionally.

The traditional functions of banking are limited to accept deposits and to give loans and advances. Ever since the liberalisation in India, this sector has been growing without Leaps and bounces and catering to the needs of various segments of the 
society. In recent times, the Banking Sector has been making rapid straights by using information technology as a platform and endeavouring to scale higher heights. Liberalization and Information technology has attracted many foreign banks to India, thereby opening up new markets, new products and efficient delivery channels for the banking industry. In the development of Indian Economy, Banking sector plays a very important and crucial role.

Commercial Banks in India are now becoming a one-stop Supermarket. The focus is shifting from mass banking to class banking with the introduction of value added and customized products. Banks plays an important role in the economic development of developing countries. Economic development involves investment in various sectors of the economy. The bank collects savings for investment in various projects. In normal banking the banks perform agency services for their customers and helps economic development of the country. The purchase and sales securities, shares, make payments, receive subscription funds and collect utility bills for the Government department. There for banks save time and energy of busy peoples. Bank arranges foreign exchange for the business transactions with other countries. Banking sector are not simply collecting funds but also serve as a guide to the customer about the investment of their money.

\section{OBJECTIVES OF STUDY}

1. To explain the changing banking scenario.

2. To analysis of the impact of liberalization Privatization and Globalization.

3. To explain the challenges of National and commercial banks in changing banking scenario.

4. To study the opportunities for the national and commercial banks in changing banking scenario.

\section{METHODOLOGY OF STUDY}

This study is based on the analysis of the changing banking scenario in the India with the help of secondary data collection.

\section{Present Scenario}

Today role of banking industry is very important as one of the leading and mostly essential service sector. India is the largest economy in the world having more than 130 crore population. Today in India the service sector is contributing half of the Indian GDP and the banking is most popular service sector in India. The significant role of banking industry is essential to speed up the social economic development. 


\section{Structure of Indian Banking}

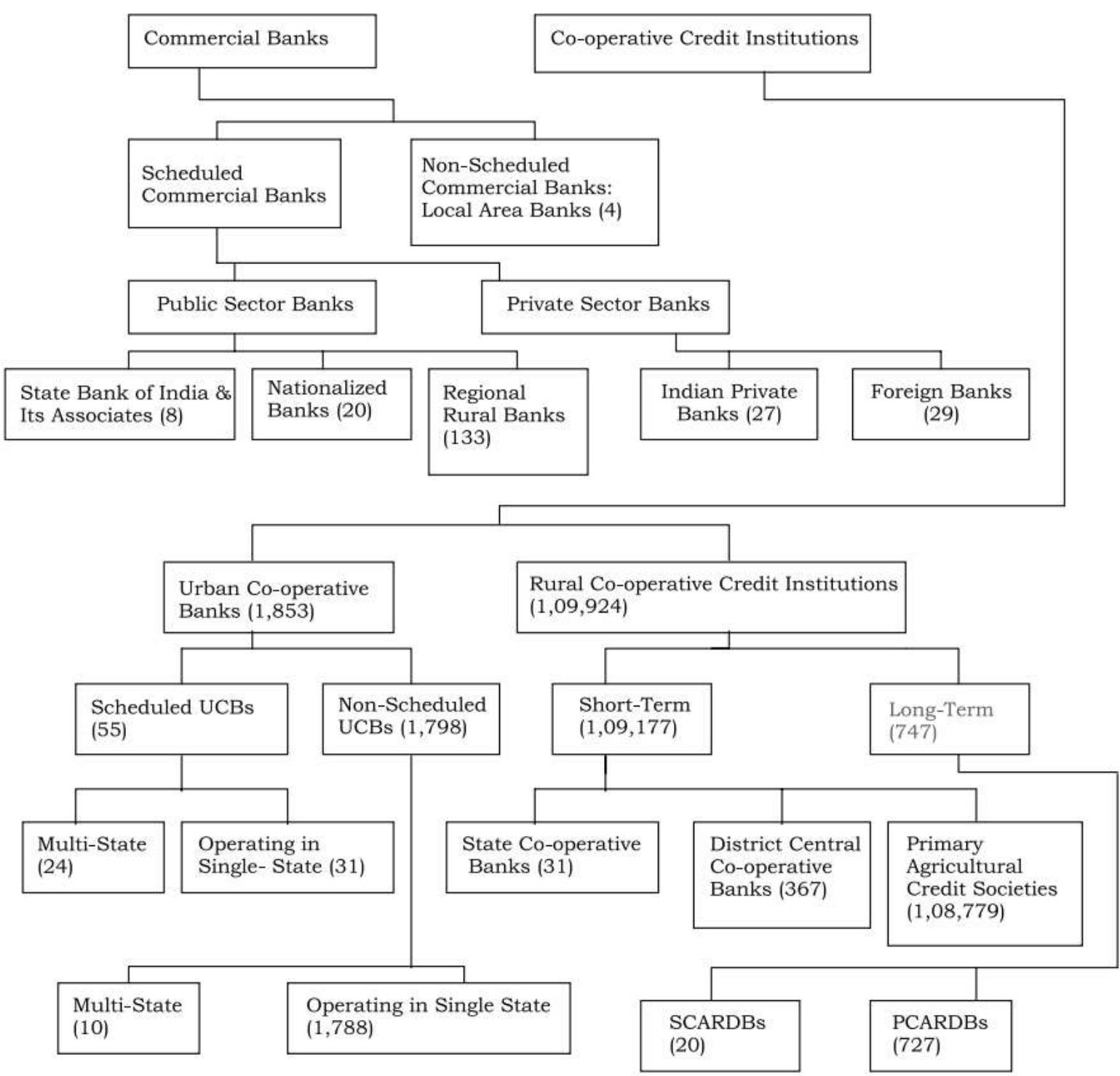

SCARDs: State Co-operative Agriculture and Rural Development Banks.

UCBs: Urban Co-operative Banks

PCARDBs: Primary Co-operative Agriculture and Rural Development Banks.

Note: Figures in brackets indicate the number of institutions at end-March 2006. However, for rural co-operative credit institutions, the number is at end-March-2005. 
Table No. 1 - Progress of Commercial Banking at A Glance

\begin{tabular}{|l|c|c|c|c|c|c|c|c|c|}
\hline $\begin{array}{l}\text { IMPORTANT } \\
\text { INDICATORS }\end{array}$ & $\begin{array}{c}\text { June } \\
\mathbf{1 9 6 9}\end{array}$ & $\begin{array}{c}\text { March } \\
\mathbf{2 0 0 5}\end{array}$ & $\begin{array}{c}\text { March } \\
\mathbf{2 0 0 6}\end{array}$ & $\begin{array}{c}\text { March } \\
\mathbf{2 0 0 7}\end{array}$ & $\begin{array}{c}\text { March } \\
\mathbf{2 0 0 8}\end{array}$ & $\begin{array}{c}\text { March } \\
\mathbf{2 0 0 9}\end{array}$ & $\begin{array}{c}\text { March } \\
\mathbf{2 0 1 0}\end{array}$ & $\begin{array}{c}\text { March } \\
\mathbf{2 0 1 1}\end{array}$ & $\begin{array}{c}\text { March } \\
\mathbf{2 0 1 2}\end{array}$ \\
\hline $\begin{array}{l}\text { No. of Commercial } \\
\text { Banks }\end{array}$ & 89 & 288 & 222 & 183 & 175 & 170 & 169 & 169 & 173 \\
\hline $\begin{array}{l}\text { (a) Scheduled } \\
\text { Commercial Banks }\end{array}$ & 73 & 284 & 218 & 179 & 171 & 166 & 165 & 165 & 169 \\
\hline $\begin{array}{l}\text { Of which: Regional } \\
\text { Rural Banks }\end{array}$ & - & 196 & 133 & 96 & 91 & 86 & 82 & 82 & 82 \\
\hline $\begin{array}{l}\text { (b) Non-Scheduled } \\
\text { Commercial Banks }\end{array}$ & 16 & 4 & 4 & 4 & 4 & 4 & 4 & 4 & 4 \\
\hline $\begin{array}{l}\text { No. of Offices of } \\
\text { Scheduled Commercial } \\
\text { Banks in India }\end{array}$ & 8262 & 68355 & 69471 & 71839 & 76050 & 80547 & 85393 & 90263 & 98330 \\
\hline (a) Rural & 1833 & 32082 & 30579 & 30551 & 31076 & 31667 & 32624 & 33683 & 36356 \\
\hline (b) Semi-Urban & 3342 & 15403 & 15556 & 16361 & 17675 & 18969 & 20740 & 22843 & 25797 \\
\hline (c) Urban & 1584 & 11500 & 12032 & 12970 & 14391 & 15733 & 17003 & 17490 & 18781 \\
\hline (d) Metropolitan & 1503 & 9370 & 11304 & 11957 & 12908 & 14178 & 15026 & 16247 & 17396 \\
\hline $\begin{array}{l}\text { Population } \\
\text { per office } \\
\text { (in thousands) }\end{array}$ & 64.0 & 16.0 & 16.0 & 15.0 & 15.0 & 14.5 & 13.8 & 13.4 & 12.3 \\
\hline
\end{tabular}

Source: Basic Statistical Returns of Scheduled Commercial Banks in India - Volume 41,2012

The present banking scenario provides a lot of opportunities as well as facing lot of challenges also. In the past few years we observed that there was lot of down and up trends in banking sector due to the global finance crisis. In India it has not major affected but in America still the economy is under the pressure of economic crisis. India is being fundamentally strong supported by concrete economic policies, decisions and implementations by the Indian Government i.e. Prime Minister Dr. Manmohan Singh. Banking sector are not major affected but definitely there was reflection on the share market.

To improve major areas of banking sector Govt. of India. RBI, Ministry of finance have made several notable efforts. Many of leading banks operating in market have made use of the changed rules and regulations such as CRR, Interest Rates Special offers to the customers such as to open account in zero balance. Now days almost all banks entered into all areas of banking services. As a result of innovation banking products are a reality now. Even saving accounts have become subject of innovation. Due to liberalization, Privatization and Globalization, Indian banks going global and many global banks setting up shops in India. The Indian banking system is set to involve into a totally new level. It will help the banking system to grow in strength going into future. Due to liberalization banks are operating on reduced spread main focus is highlighted on consumerism and how to customers linked and remain attached with the bank. Therefore banks are entered these days in non banking products such insurance in which area there are tremendous opportunities.

\section{CHALLENGES}

\section{1) Customer Satisfaction}

Today in sector customers are more value oriented in their services because they have alternative choices in it. So that each and every bank have to take care about fulfil of our customers satisfaction.

\section{2) To provide several personnel services}

The present times demanded that banks are to provide several services for which they have to expanse in service, social banking with financial possibilities, selective up gradation, computerization and innovative mechanization, better customer services, effective managerial culture, internal supervision and control, adequate profitability, strong organization culture etc. Therefore banks must be able to provide complete personal service to the customers who comes with expectations.

\section{3) Nonperforming assets (N.P.A)}

Nonperforming assets are another challenge to the banking sector. Vehicle loans and unsecured loans increases N.P.A. which terms $50 \%$ of banks retail portfolio was also hit due to upward movement in interest rates, restrictions on collection practices and soaring real estate prices. So that every bank have to take care about regular repayment of loans. 


\section{4) Competition}

The nationalize banks and commercial banks have the competition from foreign and new private sector banks. Competition in banking sector brings various challenges before the banks such as product positioning, innovative ideas and channels, new market trends, cross selling's ad at managerial and organizational part this system needs to be manage, assets and contain risk. Banks are restricting their administrative folio by converting manpower into machine power i.e. banks are decreasing manual powers and getting maximum work done through machine power. Skilled and specialized man power is to be utilized and result oriented targeted staff will be appointed.

\section{5) Managing Technology}

Developing or acquiring the right technology, deploying it optimally and then leveraging it to the maximum extent is essential to achieve and maintain high service and efficiency standards while remaining cost effective and delivering sustainable return to shareholders. Early adopters of technology acquire significant competitive advances Managing technology is therefore, a key challenge for the Indian banking sector.

\section{6) Other Challenges}

a) Coping with regulatory reforms

b) Development of skill of bank personnel

c) Customer awareness and satisfaction

d) Corporate governance

e) Changing needs of customers

f) Keeping space with technology up gradation

g) Lack of common technology standards for mobile banking

h) Sustaining healthy bottom lines and increasing shareholders value

i) Structural changes

j) Man power planning

\section{OPPORTUNITIES}

Where there are challenges, there must opportunities. Following are the opportunities for the nationalised and commercial banks.

\section{1) Rural area customers}

Contributing to $70 \%$ of the total population in India is a largely untapped market for banking sector. In all urban areas banking services entered but only few big villages have the banks entered. So that the banks must reach in remaining all villages because majority of Indian still living in rural areas.

\section{2) Offering various Channels}

Banks can offer so many channels to access their banking and other services such as ATM, Local branches, Telephone/mobile banking, video banking etc to increase the banking business.

\section{3) Good Customer Services}

Good customer services are the best brand ambassador for any bank for growing its business. Every engagement with customer is an opportunity to develop a customer faith in the bank. while increasing competition customer services has become the backbone for judging the performance of banks.

\section{4) Internet Banking}

It is clear that online finance will pickup and there will be increasing convergence in terms of product offerings banking services, share trading, insurance, loans, based on the data warehousing and data mining technologies. Anytime anywhere banking will become common and will have to upscale, Such upscaleing could include banks launching separate internet banking services apart from traditional banking services.

\section{5) Retail Lending's}

Recently banks have adopted customer segmentation which has helped in customizing their product folios well. Thus retail lending's has become a focus area particularly in respect of financing of consumer durables, housing, automobiles etc., Retail lending's has also helped in risks dispersal and in enhancing the earnings of banks with better recovery rates.
6) Other Opportunities
a) To enter new business and new markets
b) To develop new ways of working
c) To improve efficiency
d) To deliver high level of customer services.

\section{CONCLUSION}

Finally the banking sector will need to master a new business model by building management and customer services. Banks should contribute intensive efforts to render better services to their customer, Nationalized and commercial banks should overcome the challenges and to get advantage of opportunities in changing banking scenario.

\section{REFERENCES}

1. N.K. Thingalaya, "Manu, Chanakya and the Rate of Interest", Pigmy Economic Review, Vol. 36, Aug Oct, 1994, pp. 1-5.

2. Niti Bhasin: (2007) "Banking development in India 1947 to 2007 " century publication Delhi 110005.

3. c. Kugumakara Hebbar, "Growth of Banking in India Before Independence", Pigmy Econgmic Review, August 1989 , pp .3 -4.

4. Romeo S. Mascarenhas (2008) "Marketing in banking and Insurance" Vipul prakashan Mumbai 400004

5. Uppal R.K. (2007) "Banking services and information Technology” New century publications, new delhi.

6. Mishra S.K., Puri V.K.: Economic Environment of Businss, Himalaya Publishing House, 2002, P. 28.

7. www.rbi.org.in 